\title{
PENERAPAN TEKNOLOGI BUDIDAYA JENUH AIR PADA EMPAT VARIETAS KEDELAI DI RAWA LEBAK DENGAN PENAMBAHAN AMELIORAN YANG MENGANDUNG KALSIUM ALAMI
}

\section{APPLICATION OF WATER SATURATION CULTURE TECHNOLOGY IN FOUR VARIETIES SOYBEAN IN SWAMP LAND WITH AMELIORAN ADDITION CONTAINING NATURAL CALCIUM}

\author{
Edi Susilo, Hety Novitasari dan Novita Hamron* \\ *Fakultas Pertanian Universitas Ratu Samban \\ J1. Jenderal Sudirman No. 87 Arga Makmur Kabupaten Bengkulu Utara \\ Korespondensi : e-mail : susilo_agr@yahoo.com
}

\begin{abstract}
ABSTRAK
Kebutuhan kedelai semakin meningkat seiring meningkatnya jumlah penduduk dan kesadaran gizi, tetapi produksi nasional belum mencukupi. Program ekstensifikasi pertanian dapat dilakukan di lahan sub-optimal. Salah satunya adalah lahan rawa lebak. Budidaya jenuh air merupakan penanaman dengan memberikan irigasi terus-menerus dari awal tanam sampai panen. Terdapat masalah budidaya di lahan rawa lebak ini, diantaranya masih rendahnya $\mathrm{pH}, \mathrm{Al}$ dan $\mathrm{Fe}$ tinggi. Salah satu strategi yang dapat ditempuh adalah pemberian amelioran. Amelioran yang mengandung kalsium mempunyai potensi terhadap perbaikan sifat kimia tanah. Penelitian dilaksanakan Maret sampai Juni 2019, di Rumah Plastik Fakultas Pertanian Universitas Ratu Samban Arga Makmur Bengkulu Utara. Penelitian ini dilaksanakan dengan menggunakan rancangan acak kelompok (RAK) dengan dua faktor. Faktor pertama varietas kedelai terdiri atas : V1 : varietas Detam 1. V2 : varietas Detam 3, V3 : varietas Detam 4, V4 : varietas Anjasmoro. Faktor kedua sumber amelioran terdiri atas : A0 : tanpa amelioran (kontrol), A1 : amelioran batu karang, A2 : amelioran cangkang telur, A3 : amelioran cangkang lohan, A4 : amelioran tulang sapi. Penelitian bertujuan untuk mendapatkan informasi tentang amelioran untuk perbaikan budidaya kedelai di rawa lebak. Hasil penelitian menunjukkan bahwa varietas Anjasmoro menghasilkan komponen vegetatif (tinggi, jumlah daun, jumlah cabang) dan komponen generatif (bobot 100 butir dan bobot biji per tanaman) tertinggi. Varietas Detam 3 atau Detam 4 menghasilkan bobot biji per tanaman lebih baik. Amelioran tulang sapi menghasilkan komponen vegetatif dan generatif yang lebih tinggi. Tidak terdapat interaksi antara perlakuan varietas dan amelioran.
\end{abstract}

Kata kunci : jenuh air, varietas, rawa lebak, amelioran.

\section{ABSTRACT}

Soybean needs are increasing with increasing population and nutritional awareness, but national production has not been sufficient. The agricultural extensification program can be carried out on sub-optimal land. One of them is swamp land. Water saturated cultivation is planting by providing continuous irrigation from the beginning of planting to harvest. There are cultivation problems in this swamp land, including low $\mathrm{pH}$, high $\mathrm{Al}$ and $\mathrm{Fe}$. One strategy that can be taken is the provision of ameliorant. The study was conducted from March to June 2019, at the Green House of the Faculty of Agriculture, University of Ratu Samban Arga Makmur, Bengkulu Utara. This study used a randomized block design with two factors. The first factor consists of soybean varieties: V1: Detam 1 variety, V2: Detam 3 variety, V3: Detam 4 variety, and V4: Anjasmoro variety. The second factor of amelioran source consists of: A0 : without amelioran, A1: amelioran of rock, A2: amelioran of egg shell, A3: amelioran of lokan shell, A4: amelioran of cow bone. The research aims to obtain 
information about ameliorant to improve soybean cultivation in swamp land. The results showed that the Anjasmoro variety produced the highest vegetative component (height, number of leaves, number of branches) and generative component (weight of 100 grains and weight of seeds per plant). Detam 3 or Detam 4 varieties produce better seed weight per plant. Amelioran cow bone produce higher vegetative and generative components. There was no interaction between varieties and ameliorant treatments.

Keywords: saturated water, varieties, swamp land, ameliorant

\section{PENDAHULUAN}

Kedelai merupakan salah satu tanaman yang mempunyai nilai ekonomi baik karena bermanfaat sebagai bahan baku makanan khas masyarakat Indonesia seperti tempe, tahu, kecap dan olahan pangan lainnya. Kebutuhan kedelai nasional semakin meningkat seiring meningkatnya jumlah penduduk dan kesadaran akan gizi, tetapi produksi belum mencukupi. Berdasarkan data BPS (2013) produktivitas kedelai Indonesia pada tahun 2012 mengalami penurunan sebesar 1,32 t/ha dibandingkan tahun 2011 dan diikuti penurunan luasan panen 55.252 ha.

Program ekstensifikasi pertanian dapat dilakukan di suboptimal. Salah satu lahan suboptimal yang ada di Indonesia adalah lahan rawa lebak. Lahan rawa merupakan salah satu alternatif dalam mengatasi semakin menyusutnya lahan subur di pulau Jawa akibat konversi lahan dari lahan pertanian menjadi lahan untuk industri atau pemukiman. Luas lahan pasang surut di Indonesia diperkirakan sekitar 20,1 juta ha, dan sekitar 9,53 juta ha dan berpotensi untuk dijadikan sebagai lahan pertanian (Alihamsyah, 2004).

Teknik konvensional yang dilakukan pada budidaya kedelai saat ini merupakan teknik budidaya yang menghasilkan produktivitas persatuan lahan yang relatif kecil sampai sedang saja. Namun teknik budidaya secara konvensional tersebut bisa diatasi dengan teknologi budidaya jenuh air. Budidaya jenuh air (BJA) merupakan penanaman di atas bedengan dengan memberikan air secara terus menerus di dalam parit, sehingga tanah di bawah perakaran menjadi jenuh air tetapi tidak tergenang (Purwaningrahayu et al., 2004). Keadaan jenuh air pada perakaran risosfir pertanaman merupakan keadaan yang optimal untuk pertumbuhan dan perkembangan tanaman. Budidaya di rawa dengan potensi yang bisa diterapkan budidaya jenuh air, namun terdapat tantangan dalam budidaya di lahan rawa tersebut, diantaranya masih rendahnya $\mathrm{pH}$ dan tingginya $\mathrm{Al}$ maupun $\mathrm{Fe}$. 
Perbaikan lahan rawa diperlukan demi keberlangsungan budidaya pertanian yang produktif. Salah satu untuk perbaikan lahan tersebut adalah menggunakan amelioran untuk perbaikan sifat fisik dan kimia tanah. Tujuan pemberian amelioran adalah salah satu upaya untuk memperbaiki lahan dari kondisi tidak subur menjadi lahan yang cukup subur dan produktif sehingga kendala dalam budidaya di lahan rawa dapat diminimalisir. Pemberian input dalam bentuk amelioran pada tanah dapat mengubah dan memperbaiki sifat-sifat fisik maupun kimia. Salah satu contoh jenis amelioran yang dapat memperbaikan kesuburan tanah adalah amelioran yang mengandung kalsium alami. Bahan yang mengandung kalsium alami yang dimaksud disini adalah bahan yang ada di alam yang berpotensi mengandung unsur kalsium. Bahanbahan tersebut umumnya berserakan di sekitar kita dan umumnya kurang termanfaatkan bahkan menjadi pemandangan yang kurang menarik karena terkesan sebagai tumpukan sampah. Bahan-bahan alami yang diduga mengandung unsur kalsium tersebut apabila bahan tersebut dijadikan amelioran pada tanah yang miskin unsur hara terutama tanah yang ber-pH rendah maka hal ini menjadi alternatif dalam perbaikan lahan suboptimal khususnya rawa lebak. Penelitian ini bertujuan untuk mendapatkan informasi tentang amelioran yang mengandung kalsium alami sehingga menjadi bahan alternatif amelioran pada budidaya kedelai jenuh air di lahan rawa lebak.

\section{BAHAN DAN METODE}

Penelitian dilaksanakan Maret sampai Juni 2019. Penelitian dilaksanakan di Rumah Plastik Fakultas Pertanian Universitas Ratu Samban Arga Makmur Bengkulu Utara. Bahan penelitian yang digunakan adalah benih kedelai varietas Detam 1, Detam 3, Detam 4, Anjasmoro, tanah rawa, pupuk organik, batu karang, cangkang telur, cangkang lokan, tulang, dan pupuk anorganik. Peralatan yang digunakan cangkul, sabit, timbangan, meteran, tali rafia, ajir, ember, kantong, parang, pisau, polybag, baki atau nampan, lakban, kertas label, pengaduk, ember, plastik, dan alat tulis.

Penelitian ini dilaksanakan dengan menggunakan rancangan acak kelompok (RAK) dengan dua faktor. Faktor pertama varietas kedelai terdiri atas : V1 : varietas Detam 1. V2 : varietas Detam 3, V3 : varietas Detam 4, V4 : varietas Anjasmoro. Faktor kedua sumber amelioran terdiri atas : A0 : tanpa amelioran (kontrol), A1 : amelioran batu karang, A2 : amelioran cangkang telur, A3 : amelioran cangkang lohan, A4 : 
amelioran tulang sapi. Terdapat 20 kombinasi perlakuan tersebut $\mathrm{di}$ atas diulang enam kali sehingga terdapat 120 satuan percobaan.

$$
\text { Kegiatan awal adalah }
$$
pengumpulan media topsoil tanah rawa lebak. Media tanah dikumpulkan menjadi satu dan dicampur dengan pupuk organik berupa pupuk kandang sapi. Setelah media tanah dan pupuk kandang dicampur secara komposit, merata dan homogen maka media tersebut dimasukkan ke dalam polybag. Media tanam dalam polybag disusun sesuai denah percobaan yang telah dibuat. Media tanah dalam polybag ini dibiarkan sepuluh hari dengan tujuan untuk mendapatkan media matang atau media yang baik untuk pertumbuhan tanaman.

Media tanam dengan semua perlakuan menggunakan baki sebagai simulasi penerapan teknologi budidaya jenuh air. Perlakuan jenuh air mempunyai arti bahwa media polybag ini digenangi air dengan ketinggian $15 \mathrm{~cm}$ di baki atau nampannya. Demikian juga perlakuan amelioran yang diberikan sesuai dengan perlakuan yang diterapkan.

Benih kedelai ditanam pada media tanam sebanyak 4 benih per polybag. Cara tanamnya adalah media tanah di polybag dibuat lubang tanam sebanyak 4 lubang sedalam $3 \mathrm{~cm}$, benih dimasukkan ke lubang tanam 1 benih per lubang tanam dan ditutup dengan topsoil. Dilakukan penyiraman untuk mendapatkan media yang basah dan menghasilkan pertumbuhan awal yang normal. Selanjutnya, tanaman setelah berumur 2 minggu setelah tanam (MST) maka tanaman yang awalnya 4 tanaman per polybag dikurangi dengan menyisakan 2 tanaman per polybag saja.

Pemeliharaan tanaman meliputi pemupukan dengan pupuk anorganik, pengendalian hama penyakit dan gulma. Pemupukan dilakukan dengan cara menugal $5 \mathrm{~cm}$ dari lubang tanam. Setengah dari dosis Urea (200 kg/ha) diberikan pada saat tanam dan selebihnya pada 4 MST. Sedangkan SP36 (100 kg/ha) dan $\mathrm{KCl}(100 \mathrm{~kg} / \mathrm{ha})$ seluruhnya diberikan pada saat tanam. Pengendalian hama dan penyakit dilakukan secara berkala seminggu sekali dimulai umur 2 MST. Pengendalian gulma dilakukan secara manual pada umur 2 MST, 5 MST, dan 8 MST.

Panen kedelai dilakukan bila daun telah berwarna kuning dan rontok, 90\% polong berwarna coklat. Pemanenan kedelai dilakukan dengan mencabut batangnya kemudian berangkasan dimasukkan dalam kantong kertas dan diberi label sesuai dengan kode perlakuan.

Data dikumpulkan dari semua tanaman sampel yang diukur. Data yang 
terkumpul selanjutnya dianalisis secara statistik. Pengukuran kedelai meliputi: tinggi tanaman, jumlah daun, jumlah cabang, bobot 100 biji dan bobot biji $\tan ^{-1}$. Data hasil pengamatan dianalisis dengan sidik ragam, apabila dari hasil analisis tersebut berpengaruh nyata maka dilanjutkan dengan uji wilayah berganda Duncan (DMRT) pada taraf kepercayaan 95\% (Mattjik dan Sumertajaya, 2006).

\section{HASIL DAN PEMBAHASAN}

Hasil Rekapitulasi sidik ragam pertumbuhan dan hasil kedelai dapat dilihat pada Tabel 1. Hasil analisis ragam menunjukkan bahwa terdapat pengaruh nyata perlakuan varietas terhadap tinggi tanaman, jumlah daun, jumlah cabang, bobot 100 butir dan bobot biji $\tan ^{-1}$. Perlakuan amelioran menunjukkan berpengaruh nyata terhadap variabel tinggi tanaman, jumlah daun, jumlah cabang, dan bobot biji $\tan ^{-1}$, namun tidak berpengaruh nyata pada variabel bobot 100 butir. Pada interaksi antara varietas dan amelioran menunjukkan tidak berpengaruh nyata pada semua variabel pengamatan. Hal ini menunjukkan perlakuan yang diterapkan pada percobaan ini menghasilkan respon masing-masing variabel yang hampir sama.

Pada variabel tinggi tanaman menunjukkan bahwa perlakuan varietas dan amelioran berpengaruh nyata terhadap variabel tinggi tanaman. Varietas Anjasmoro menghasilkan tinggi tanaman tertinggi $(91,33 \mathrm{~cm})$ berbeda nyata dengan varietas Detam $4(86,42 \mathrm{~cm})$ dan Detam 1 $(84,60 \mathrm{~cm})$. Hal ini menunjukkan bahwa varietas Anjasmoro mempunyai potensi yang baik untuk dikembangkan karena mempunyai sifat-sifat yang unggul khususnya variabel tinggi tanaman. Pada perlakuan amelioran menunjukkan bahwa amelioran tulang sapi dan cangkang lokan menghasilkan tinggi tanaman tertinggi masing-masing 94,68 $\mathrm{cm}$ dan 92,85 cm dan berbeda nyata dengan cangkang telur $(85,81 \mathrm{~cm})$, batu karang $(87,44 \mathrm{~cm})$ dan tanpa amelioran $(79,06 \mathrm{~cm})$ ditunjukkan Tabel 2. Hal ini menunjukkan bahwa amelioran yang berasal dari tulang sapi dan cangkang lokan berpotensi menjadi bahan amelioran yang baik untuk kedepannya. Penemuan amelioran berbahan limbah di lingkungan kehidupan manusia merupan sebuah terobosan yang baik guna memanfaatkan bahan sisa dan sebagai bahan alternatif sumber kalsium yang selama ini ada yang sudah komersil. 
Tabel 1. Rekapitulasi Sidik Ragam Pertumbuhan dan Hasil Kedelai

\begin{tabular}{clcccc}
\hline No & Variabel pengamatan & $\begin{array}{c}\text { Varietas } \\
(\mathrm{V})\end{array}$ & $\begin{array}{c}\text { Amelioran } \\
(\mathrm{A})\end{array}$ & $\begin{array}{c}\text { Interaksi } \\
(\mathrm{V} \times \mathrm{A})\end{array}$ & KK (\%) \\
\hline 1 & Tinggi tanaman & $3,70 *$ & $12,35 * *$ & $0,84 \mathrm{tn}$ & 9,80 \\
2 & Jumlah daun & $4,35 * *$ & $11,62 * *$ & $0,46 \mathrm{tn}$ & 22,48 \\
3 & Jumlah cabang & $4,47 * *$ & $18,44 * *$ & $1,66 \mathrm{tn}$ & 13,37 \\
4 & Bobot 100 butir & $42,48 * *$ & $0,20 \mathrm{tn}$ & $0,77 \mathrm{tn}$ & 12,82 \\
5 & Bobot biji tan $^{-1}$ & $4,71 * *$ & $2,46 *$ & $1,58 \mathrm{tn}$ & 28,40 \\
\hline
\end{tabular}

Keterangan: $*=$ berbeda nyata

$* *$ = berbeda sangat nyata

tn $=$ tidak berbeda nyata

Pada variabel jumlah daun menunjukkan bahwa perlakuan varietas dan amelioran berpengaruh nyata terhadap variabel jumlah daun. Varietas Anjasmoro menghasilkan jumlah daun terbanyak (31,13 helai) berbeda nyata dengan varietas Detam 4 (27,10 helai) dan Detam 1 (25,80 helai). Hal ini menunjukkan bahwa varietas Anjasmoro mempunyai potensi yang baik untuk dikembangkan karena mempunyai sifat-sifat yang unggul khususnya variabel jumlah daun. Pada perlakuan amelioran menunjukkan bahwa amelioran tulang sapi dan cangkang lokan menghasilkan jumlah daun tertinggi masing-masing 33,21 helai dan 31,94 helai dan berbeda nyata dengan cangkang telur (26,98 helai), batu karang $(28,17$ helai) dan tanpa amelioran (21,96 helai) ditunjukkan Tabel 2. Hal ini menunjukkan bahwa amelioran yang berasal dari tulang sapi dan cangkang lokan berpotensi menjadi bahan amelioran yang baik untuk dikembangkan dimasa depan.
Pada variabel jumlah cabang menunjukkan bahwa perlakuan varietas dan amelioran berpengaruh nyata terhadap variabel jumlah cabang. Varietas Anjasmoro menghasilkan jumlah cabang terbanyak (4,48 batang) berbeda nyata dengan varietas Detam 4 (4,14 batang) dan Detam 1 (4,00 batang), namun tidak berbeda nyata dengan Detam $3 \quad(4,28$ batang). Pada perlakuan amelioran menunjukkan bahwa amelioran tulang sapi menghasilkan jumlah cabang tertinggi (4,88 batang) berbeda nyata dengan cangkang lokan (4,50 batang), cangkang telur (4,30 batang), batu karang $(4,13$ batang) dan tanpa amelioran $(3,33$ batang), jumlah cabang terendah dicapai oleh tanpa amelioran ditunjukkan Tabel 3. Hal ini menunjukkan bahwa amelioran yang berasal dari tulang sapi dan cangkang lokan berpotensi menjadi bahan amelioran yang baik sebagai alternatif sebagai solusi sumber kalsium. 
Tabel 2. Rataan Tinggi Tanaman dan Jumlah Daun Beberapa Varietas Kedelai Akibat Aplikasi Amelioran

\begin{tabular}{lcc}
\hline \multicolumn{1}{c}{ Perlakuan } & Tinggi $(\mathrm{cm})$ & Jumlah daun (helai) \\
\hline Varietas : & & \\
Detam 1 (V1) & $84,60 \mathrm{c}$ & $25,80 \mathrm{c}$ \\
Detam 3 (V2) & $89,52 \mathrm{ab}$ & $29,77 \mathrm{ab}$ \\
Detam 4 (V3) & $86,42 \mathrm{bc}$ & $27,10 \mathrm{bc}$ \\
Anjasmoro (V4) & $91,33 \mathrm{a}$ & $31,13 \mathrm{a}$ \\
\hline Amelioran : & & \\
Kontrol (A0) & $79,06 \mathrm{c}$ & $21,96 \mathrm{c}$ \\
Batu karang (A1) & $87,44 \mathrm{~b}$ & $28,17 \mathrm{~b}$ \\
Cangkang telur (A2) & $85,81 \mathrm{~b}$ & $26,98 \mathrm{~b}$ \\
Cangkang lokan (A3) & $92,85 \mathrm{a}$ & $31,94 \mathrm{a}$ \\
Tulang sapi (A4) & $94,68 \mathrm{a}$ & $33,21 \mathrm{a}$ \\
\hline
\end{tabular}

Keterangan : angka-angka yang diikuti huruf yang sama pada kolom yang sama tidak berbeda nyata pada uji DMRT taraf 5\%.

Tabel 3. Rataan Jumlah Cabang Beberapa Varietas Kedelai Akibat Aplikasi Amelioran

\begin{tabular}{lc}
\hline \multicolumn{1}{c}{ Perlakuan } & Jumlah cabang (batang) \\
\hline Varietas : & \\
Detam 1 (V1) & $4,00 \mathrm{~b}$ \\
Detam 3 (V2) & $4,28 \mathrm{ab}$ \\
Detam 4 (V3) & $4,14 \mathrm{~b}$ \\
Anjasmoro (V4) & $4,48 \mathrm{a}$ \\
\hline Amelioran : & $3,33 \mathrm{~d}$ \\
Kontrol (A0) & $4,13 \mathrm{c}$ \\
Batu karang (A1) & $4,30 \mathrm{bc}$ \\
Cangkang telur (A2) & $4,50 \mathrm{~b}$ \\
Cangkang lokan (A3) & $4,88 \mathrm{a}$ \\
Tulang sapi (A4)
\end{tabular}

Keterangan : angka-angka yang diikuti huruf yang sama pada kolom yang sama tidak berbeda nyata pada uji DMRT taraf $5 \%$.

Pada variabel bobot 100 butir tanaman tersebut. Pada perlakuan menunjukkan bahwa perlakuan varietas berpengaruh nyata terhadap bobot 100 butir. Varietas Anjasmoro menghasilkan bobot 100 butir tertinggi $(16,68 \mathrm{~g})$ amelioran menunjukkan tidak berpengaruh nyata terhadap variabel bobot 100 butir ditunjukkan Tabel 4 . Pada variabel bobot biji per
tanaman menunjukkan bahwa perlakuan
varietas dan amelioran berpengaruh nyata.
Varietas Anjasmoro dan Detam 4
menghasilkan bobot biji per tanaman
tertinggi masing-masing $20,20 \mathrm{~g}$ dan berbeda nyata dengan varietas Detam 4 (12,21 g), Detam 3 (12,32 g), dan Detam $1(14,63 \mathrm{~g})$. Bobot 100 butir merupakan gambaran ukuran biji. Besarnya ukuran biji biasanya ditentukan oleh genetik dari 
$20,17 \mathrm{~g}$ dan berbeda nyata dengan varietas Detam 3 (17,79 g) dan Detam 1 (15,88 g). Hasil penelitian pengembangan bertanam kedelai di tanah jenuh air menunjukan bahwa dengan budidaya jenuh air diperoleh peningkatan hasil biji kedelai mencapai 2,4 ton/ha (Sumarno,1986). Pada perlakuan amelioran menunjukkan bahwa amelioran tulang sapi menghasilkan bobot biji per tanaman tertinggi, namun tidak berbeda nyata dengan cangkang telur, cangkang lokan dan batu karang, dan berbeda nyata dengan tanpa amelioran ditunjukkan Tabel 4. Hal ini menunjukkan bahwa amelioran yang berasal dari tulang sapi dan cangkang lokan berpotensi menjadi bahan amelioran yang baik sebagai bahan alternatif amelioran sumber kalsium. Kecukupan akan hara pada tanaman akan semakin sempurna. Fransiscus (2006) melaporkan bahwa apabila tanaman memperoleh unsur hara yang cukup mengakibatkan fotosintesis akan berlangsung dengan baik, sehingga penumpukan bahan-bahan organik hasilhasil fotosintasis dalam biji lebih banyak dan akan berpengaruh pada produksi tanaman. Selanjutnya penelitian Susilo, et al., (2019) perlakuan dosis amelioran batu karang terbaik yaitu 9 g per tanaman dan mampu meningkatkan tinggi, jumlah daun dan kecenderungan pada bobot biji per tanaman kedelai.

Tabel 4. Rataan Bobot 100 Butir dan Bobot Biji Per Tanaman Beberapa Varietas Kedelai Akibat Aplikasi Amelioran

\begin{tabular}{lcc}
\hline \multicolumn{1}{c}{ Perlakuan } & $\begin{array}{c}\text { Bobot } 100 \text { butir } \\
(\mathrm{g})\end{array}$ & $\begin{array}{c}\text { Bobot biji } \tan ^{-1} \\
(\mathrm{~g})\end{array}$ \\
\hline Varietas : & $14,63 \mathrm{~b}$ & $15,88 \mathrm{~b}$ \\
Detam 1 (V1) & $12,32 \mathrm{~b}$ & $17,79 \mathrm{ab}$ \\
Detam 3 (V2) & $12,21 \mathrm{c}$ & $20,17 \mathrm{a}$ \\
Detam 4 (V3) & $16,68 \mathrm{a}$ & $20,20 \mathrm{a}$ \\
Anjasmoro (V4) & & \\
\hline Amelioran : & $13,80 \mathrm{a}$ & $16,46 \mathrm{~b}$ \\
Kontrol (A0) & $14,14 \mathrm{a}$ & $17,35 \mathrm{ab}$ \\
Batu karang (A1) & $13,79 \mathrm{a}$ & $19,90 \mathrm{a}$ \\
Cangkang telur (A2) & $14,10 \mathrm{a}$ & $18,35 \mathrm{ab}$ \\
Cangkang lokan (A3) & $13,96 \mathrm{a}$ & $20,47 \mathrm{a}$ \\
Tulang sapi (A4) &
\end{tabular}

Keterangan : angka-angka yang diikuti huruf yang sama pada kolom yang sama tidak berbeda nyata pada uji DMRT taraf $5 \%$. 


\section{KESIMPULAN}

Varietas Anjasmoro menghasilkan komponen vegetatif (tinggi, jumlah daun, jumlah cabang) dan komponen generatif (bobot 100 butir dan bobot biji per tanaman) tertinggi. Varietas Detam 3 atau Detam 4 berpotensi menghasilkan bobot biji per tanaman lebih baik. Amelioran tulang sapi menghasilkan komponen vegetatif dan generatif yang lebih tinggi. Tidak terdapat interaksi antara perlakuan varietas dan amelioran.

\section{DAFTAR PUSTAKA}

Alihamsyah T. 2004. Potensi dan Pendayagunaan Lahan Rawa untuk Peningkatan Produksi Padi dan Beras Indonesia. Dalam. F. Kasrino, E. Pasandaran, dan AM. Padi (Penyunting). Badan Litbang Pertanian.

BPS] Badan Pusat Statistik. 2013. Produksi, Luas Panen dan Produktivitas Palawija di Indonesia. www.bps.go.id [22 September 2013].
Fransiscus. 2006. Pemberian beberapa pupuk organik terhadap pertumbuhan dan produksi kacang tanah (Arachis hypogea L). [Skripsi]. FP-Unri, Pekanbaru.

Mattjik A A, I. M Sumertajaya., 2006. Perancang Percobaan dengan Aplikasi SAS dan MINITAB. Bogor: IPB Press.

Purwaningrahayu, R. D., D. Indradewa, dan B.H. Sunarminto. 2004. Peningkatan hasil beberapa varietas kedelai dengan penerapan teknologi basah. Penelitian Pertanian Tanaman Pangan. 23(1):49-58.

Sumarno. 1986. Response of soybean (Glycine $\max$ L. Merr.) genotypes to continuees saturated culture. Indonesian Journal of Crop Scince 2 (2) : 71-78.

Susilo, E., A. Kinata, D, Novita., 2019. Pertumbuhan dan Hasil Kedelai dengan Penggunaan Amelioran Batu Karang pada Lahan Rawa Lebak menggunakan Teknologi Budidaya Jenuh Air. Jurnal Agroqua Vol. 17 No. 01 Juni 2019. ISSN : 2598-4017. Hal. 819.

https://journals.unihaz.ac.id/index. $\mathrm{php/}$ agroqua/issue/view/122 